DOI: 10.46340/eppd.2021.8.6.7

Volodymyr Komarnytskyy

ORCID ID: https://orcid.org/0000-0001-8822-3302

Uzhhorod National University, Ukraine

\title{
MODEL OF EFFECTIVE COMMUNICATION IN THE SYSTEM OF LOCAL GOVERNMENT IN UKRAINE
}

\author{
Володимир Комарницький \\ Ужгородський національний університет, Україна \\ МОДЕЛЬ ЕФЕКТИВНОЇ КОМУНІКАЦІї \\ У СИСТЕМІ МІСЦЕВОГО САМОВРЯДУВАННЯ \\ В УКРАЇ̈I
}

\begin{abstract}
It is stated that in Ukraine communication has become an important area of activity of political actors and institutions, in particular, in the system of local self-government. Communication interactions take place within the specified system with the participation of institutions of the executive branch of government in the non-institutional plane, for this reason, the circle of subjects of communication is constantly increasing. This conditioned the need to streamline and structure the communication component of regional policy, considering the institutional, corporate, and individual needs of political subjects, and also the demand of the society for the openness of public authority.

Given the defined need, the author proposes a two-level model of effective communication in the system of local self-governance in Ukraine. It covers the levels of internal and external communication. On the first level: interparty cooperation takes place (interaction between party organizations, between factions in councils, between party members within the limits of work of standing commission to ensure effective work of the representative body); integrative interaction (communication between local government administration and executive authority); interbudgetary interaction on the level "region - center"; consolidation of authorities (balancing and harmonization of the functions of newly formed councils of different levels). The second (external) level covers institutional inclusion as a means of increasing the presence of local government bodies and their officials in the life of the community through cooperation with civil society organizations; interaction with individual communicators through the ability of a citizen personally or on behalf of a particular community to send inquiries and to express an opinion; informing as a one-way communication of representatives of local government bodies; reputational programming as a tool of political, especially electoral technologies.

Keywords: political communication, local self-government, decentralization, public policy, civil society, political technologies, political institution, political party.
\end{abstract}

Постановка проблеми. Політичні комунікації, або комунікативні процеси на «вході» i «виході» політичної системи, завжди перебували уцентрі уваги вітчизняної та зарубіжної політології. Зазвичай актуалізувалися технологічні аспекти таких взаємодій, цілі комунікації та інструменти іiі реалізації. Інституційно викликали цікавість політичні еліти, гілки влади, партії, зв'язки з громадськістю. У новітніх умовах, коли децентралізація стала лейтмотивом системних перетворень в державі, акцентується політична комунікація різних рівнів та відповідні суспільнополітичні інтеракції. Отримавши більші повноваження, а разом із ними і відповідальність, органи місцевого самоврядування (далі- $\mathrm{MCB}$ ) відчули потребу в більш інтенсивних внутрішньоінституційних та зовнішніх контактах. Частина з них передбачена нормами законодавства, частина зумовлена обставинами політичної боротьби, конкуренції, а також запитами суспільства (прихильників, виборців, активістів тощо). Відтак важливо з'ясувати природу потреб комунікації у системі місцевого самоврядування, способи їх задоволення між різними комунікантами, а також визначити модель, в межах якої вказані процеси оптимізуються. 
Аналіз останніх досліджень та публікацій. Проблематика, що уособлює предметне поле дослідження, у своєму аналізі спирається на роботи, присвячені моделям комунікації (E. Гофффман, У. Еко, Ф. Елліотт, Е. Кати, Дж. Кері, П. Лазерсфельд, Г. Лассвел, У. Уївер, К. Шеннон, У. Шрамм, Р. Якобсон та ін.), теоріям політичної комунікації (Ю. Ганжуров, С. Ганущин, А. Данько-Сліпцова, С. Денисюк, М. Остапенко та ін.), комунікативному потенціалу політичних інститутів (І. Бутирська, В. Гошовська, Ю. Кокарча, Є. Романенко, Ю. Тищенко та ін.), специфіці реалізації комунікативної функції органами місцевого самоврядування (В. Гулай, Л. Демчина, І. Клименко, К. Мануілова, О. Руденко, В. Чмига, Т. Шлемкевич, С. Штурхецький та ін.). Теоретичний досвід, сформований у науковому доробку згаданих i не тільки авторів, дозволив грунтовно проаналізувати стан комунікативних взаємодій у вітчизняній системі МСВ та визначити потреби галузі.

Виклад основного матеріалу. Сучасний світ політики характеризується трансформацією сприйняття комунікації із засобу узгодження позицій та інтересів на ключовий інструмент політичної конкуренції, розширення впливу, формування команд і стабільного функціонування політичних інститутів. Комунікація - це ще й запит суспільства на новий рівень взаємодії зі сферою політики, зокрема, й у системі місцевого самоврядування. Воно, за визначенням М. Остапенко, входить до широкого кола суб'єктів політичної комунікації ${ }^{1}$ А у трактуванні Ю. Ганжурова, органи МСВ належать до інституціональних суб'єктів політичної комунікації разом із главою держави, парламентом, урядом, судовою гілкою влади, політичними партіями тощо․

В. Чмига та О. Руденко трактують комунікативний процес у місцевому самоврядування як хід становлення, розвитку і функціонування соціальної системи $\mathrm{MCB}$, який забезпечує зв'язок між людьми і їхніми спільнотами, інституціями; сприяє накопиченню, збагаченню та збереженню соціального досвіду членів територіальної громади; допомагає розподілу й організації праці та спільної діяльності; є передумовою трансляції культури ${ }^{3}$. Дослідники вказують, що комунікативним простором місцевого самоврядування $\epsilon$ «сукупність комунікативних та інформаційнокомунікативних взаємодій суб'єктів комунікації, об'єднаних спільною територією, фаховими знаннями та статусно-рольовими правилами, що визначає їхню комунікативну поведінку ${ }^{4}$.

Комунікативні взаємодії у місцевому самоврядуванні давно вийшли за суб'єктні межі відповідних органів. На сьогодні значні обсяги таких контактів відбуваються у міжінституціональній площині (наприклад, щодо бюджетного процесу), у позаінституціональному вимірі (з організаціями громадянського суспільства, окремими громадянами). Ці процеси, передусім, пов'язані з активною фазою системних реформ, як-то децентралізаційна (включно з бюджетною децентралізацією). Саме обсяг повноважень, на нашу думку, прямо пропорційно впливає на рівень затребуваності комунікативних обмінів між владою та суспільством.

Після прийняття нового Виборчого кодексу в Україні посилилося політичне значення партій, особливо на місцевому рівні, адже чинник партійної приналежності став відігравати провідну роль під час формування більшості представницьких органів влади у регіонах. Якщо раніше територіальні організації політичних партій були інструментом досягнення загальних цілей партійного керівництва та лобістських груп (потрапляння до парламенту, перемога кандидата, висунутого партією), то в умовах самоврядності новостворених об'єднаних територіальних громад партійні осередки самі напрацьовують механізми та ресурси для конкурування на місцевому рівні ${ }^{5}$. Тому й партійні та міжпартійні комунікації набули нового значення і впливів. Так, регламентуючи загальний порядок висування кандидатів організацією партії, Виборчий кодекс надав особливого значення конференціям організацій партій, де вони формують список своїх кандидатів. Ця процедура залишається одночасно i важливою публічною частиною участі партійних структур у політичному процесі, i формою прямої внутрішньопартійної комунікації. Однак, як уже зазначалося у наших попередніх наукових розвідках, 3 боку політичних партій має відбутися активізація інформаційно-комунікативної функції на всіх рівнях партійної структури, адже саме комунікація забезпечує координацію принципових позицій як партійного будівництва, так і міжінституціональної взаємодії́.

\footnotetext{
${ }^{1}$ Остапенко, М. (2012). Політична комунікація: теоретичні аспекти дослідження. Політичний менеджмент, 3, 141.

${ }^{2}$ Ганжуров, Ю. (2004). Політична комунікація: проблеми структуризації. Політичний менеджмент. 2, 125.

3 Чмига, В., Руденко, О. (2013). Комунікативний процес у місиевому самоврядуванні. Київ: НАДУ, 27.

${ }^{4}$ Там само.

${ }^{5}$ Комарницький, В. (2020). Місцеві організації політичних партій України в умовах реформи децентралізації. Політикус, 1, 26.

${ }^{6}$ Там само, 28.
} 
Потреба комунікувати об’єктивно зумовлена і переплетінням функцій інституцій різних рівнів, які й дотепер не узгоджені у законодавчій площині, а також форматом нової організації місцевої влади, коли повноваження зосереджені у невеличких громадах, а не у великих об'єднаних районах. На нашу думку, саме чинник потреби та комунікативні ролі визначають ефективність моделі комунікації, тобто системного іiі бачення у місцевому самоврядуванні. Відповідно до такого підходу виокремлюємо дворівневу модель, яка формує рівні внутрішньої та зовнішньої комунікації (рис. 1).

Рівень внутрішньої комунікації характеризується такими практиками:

- міжпартійна кооперація - передбачає взаємодію між партійними організаціями регіону, фракціями у межах представницького органу місцевого рівня, партійцями у рамках роботи постійних комісій для забезпечення ефективної роботи ради. Важливість міжпартійної кооперації доводить політична криза, яка виникла восени у Закарпатській області, коли обласні депутати двічі впродовж короткого періоду відправляли у відставку голову облради ${ }^{1}$. У цей же час через застосування маніпулятивних прийомів (повідомлення про мінування адміністративної будівлі) не відбулося кілька запланованих сесій Закарпатської обласної ради;

- інтегративна взаємодія на рівні регіону. Йдеться про комунікації між органами місцевого самоврядування та виконавчої влади - рад та адміністрацій. Така взаємодія особливо підкреслена децентралізаційними процесами, які, з одного боку, значно розширили повноваження місцевих рад, 3 іншого, залишили значний апарат місцевих органів державної виконавчої влади 3 галузевими функціями, які передбачають узгодження дій та рішень, консультації з представниками МСВ. Інтеграція зусиль та повноважень різних ланок влади на місцях $є$ запорукою стабільного розвитку громад і їхнього добробуту, врахування реальних потреб та потенціалу регіонів у реалізації державних програм та стратегій;

- міжбюджетна взаємодія на рівні «регіон - центр», яка зумовлена змінами до Податкового та Бюджетного кодексів та пов'язана зі збільшенням бюджетних повноважень органів МСВ, які здійснюються у контексті дворівневої системи взаємовідносин. Поєднання у структурі місцевих бюджетів надходжень 3 місцевих та загальнодержавних податків і зборів актуалізують питання побудови ефективної комунікації між центральними органами виконавчої влади та органами місцевого самоврядування 3 метою «формування бюджетної грамотності, поліпшення системи управління місцевими фінансами і підвищення знань профільного законодавства для працівників фінансових підрозділів по цілій країні» ${ }^{2}$;

- консолідація повноважень - один із ключових викликів для реформи децентралізації на місцевому рівні, який полягає у збалансуванні та гармонізації функціональної надбудови новостворених рад різних рівнів, що особливо відчутно затребувано для діяльності районних рад. Наразі в Україні «проєктними нормами пропонується визначити однакові повноваження для сільських, селищних та міських рад та їхніх виконавчих органів у різних сферах» ${ }^{3}$. Маються на увазі норми нового законодавства, яке розробляється за участі усіх сторін-розробників децентралізаційної реформи, а значить до комунікації залучені не лише представники МСВ, але й експертні кола, правники, урядовці та парламентарі;

Рівень зовнішньої комунікації уособлюють цільові взаємодії з певними категоріями, зокрема:

- інституціональна інклюзія як засіб збільшення присутності інституцій місцевого самоврядування та їхніх функціонерів у житті громади за допомогою співпраці з організаціями громадянського суспільства, місцевим активом. Така комунікація здійснюється організовано у форматі зустрічей, консультацій, громадських обговорень і передбачає формування регіональних програм розвитку чи розробку управлінських рішень з урахуванням думки населення через його представників;

- взаємодія з індивідуальними комунікаторами - важливий та затребуваний у сучасних умовах формат комунікації, який грунтується на можливості громадянина персонально або одноосібно від імені певної спільноти здійснювати запити чи висловлювати позицію. Передусім,

\footnotetext{
${ }^{1}$ Семенюк, А. (2021). Олексія Петрова вдруге звільнили з посади голови Закарпатської облради. Zaxid.net. <https://zaxid.net/deputati_zakarpatskoyi_oblradi_povtorno_vidpravili_oleksiya_petrova_u_vidstavku_n1530295> (2021, листопад, 22).

2 Улютін, Д. (2020). Бюджетна децентралізація: головні виклики та досягнення. Децентралізація.

$<$ https://decentralization.gov.ua/news/12661> (2021, листопад, 22).

${ }^{3}$ Негода, В. (2021). Розмежування повноважень: на розгляд Уряду направлені важливі законопроекти. Децентралізація <https://decentralization.gov.ua/news/13765> (2021, листопад, 22).
} 
ідеться про забезпечену опцію ініціювання та підтримки електронних петицій, участь у формуванні бюджетів громадської ініціативи та бюджетів участі, можливість подання запитів до уповноважених органів місцевого самоврядування, використання сервісу «Відкрите місто» та ін. Наприклад, станом на кінець листопада 2021 р., у Єдиній системі місцевих петицій таких було подано майже 5 тис. (наразі активні 243), за які проголосували понад 800 тис. осіб ${ }^{1}$;

- інформування як одностороння комунікація органів місцевого самоврядування та їхніх уповноважених посадових осіб - це функція, яку, так чи інакше, мають виконувати органи МСВ, інформуючи про свою роботу, заплановані проєкти, звітуючи про реалізовані програми тощо. Виконувати вказану комунікативну функцію можуть безпосередньо посадовці місцевого самоврядування, уповноважені ними особи, відповідні відділи у структурі виконавчих органів представницької влади на місцях. Майданчиками для інформування населення переважно є сайти органів МСB, сторінки у соціальних мережах, інші онлайн-платформи, телебачення, друковані ЗМІ тощо. Аудиторія, яка може бути охоплення таким інформуванням, зростає з року в рік, а за допомогою технологій таргетингу вона стає цільовою для місцевої влади;

- репутаційне програмування як інструмент політичних, передусім виборчих технологій. Ця робота на рівні зовнішньої комунікації - важлива складова діяльності політичних акторів, партій, посадовців органів місцевого самоврядування, адже вона забезпечує «підігрівання» виборців у міжелекторальний період, зв'язок із прихильниками, іміджеве позиціонування, комунікацію політика із опонентами або опонування їм на власному «полі» тощо. Така комунікація можлива як на відкритих зустрічах, так і в рамках активностей у соціальних мережах, де, на відміну від потреб попереднього виду взаємодій, важливо спонукати і забезпечувати зворотній зв'язок. Також до репутаційного програмування, як правило, залучені засоби масової інформації, лідери громадської думки, політичні технологи тощо.

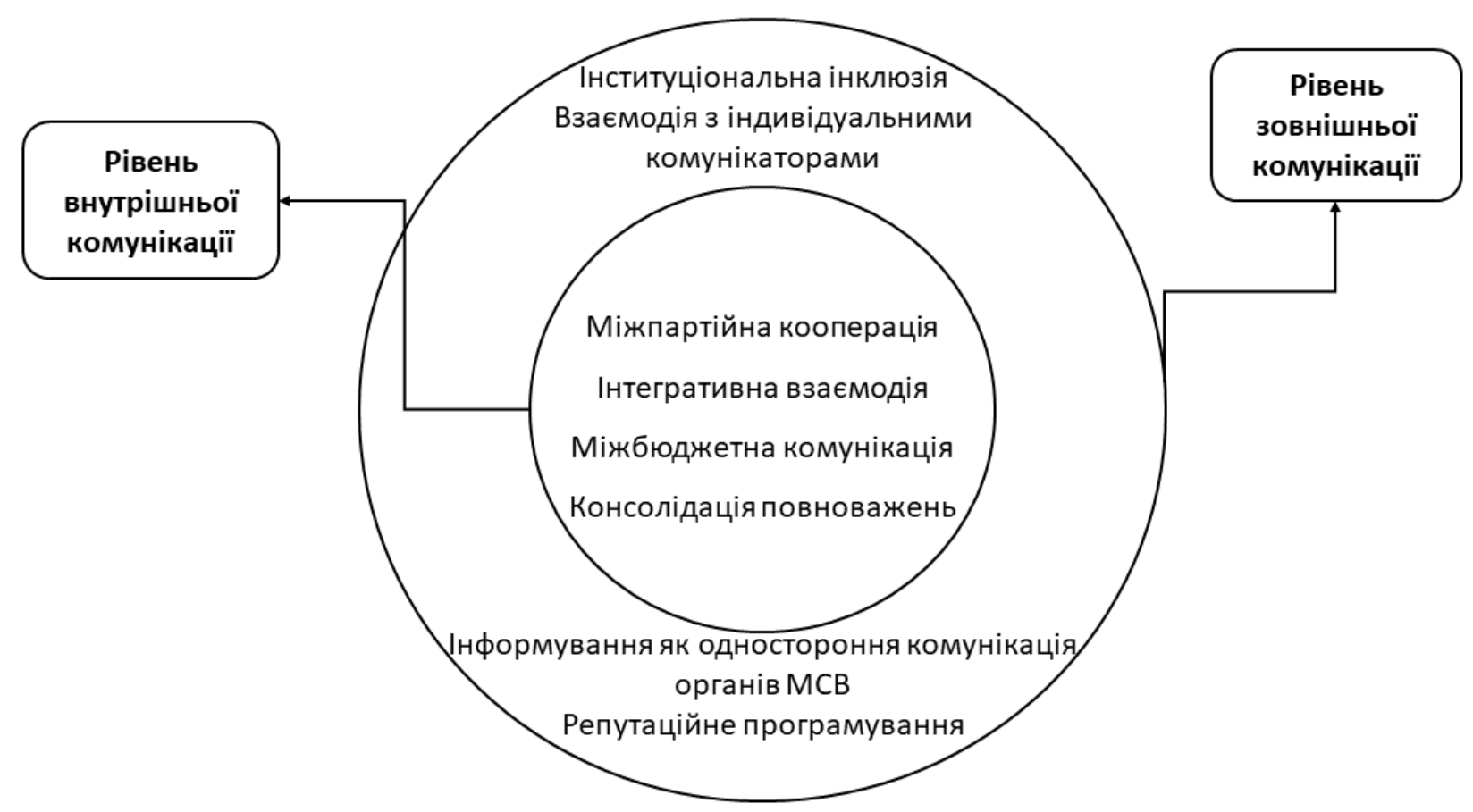

Рис. 1. Дворівнева модель ефективної комунікації у системі місцевого самоврядування в Україні

Джерело: розроблено автором

\footnotetext{
${ }^{1}$ Сдина система місцевих петицій (2021). Головна сторінка <https://petition.e-dem.ua/> (2021, листопад, 23).
} 
Наголосимо, що описані в моделі активності в межах внутрішньої та зовнішньої комунікації у системі місцевого самоврядування є зрізом інституційних, корпоративних та індивідуальних потреб регіонального політичного класу, а також нагальною необхідністю процесу підвищення рівня відкритості публічної влади. Реформа децентралізації лише посилила ці два чинника. Водночас, розвиток інформаційно-комунікативних технологій розширив можливості та набір засобів для реалізації вказаних комунікацій, збільшення залученої аудиторії та забезпечення зворотного зв'язку. Ще один важливий аспект - наявність базових нормативних умов для комплексного просування запропонованої моделі, з баченням комунікативних процесів якої, наприклад, резонують ключові принципи, зафіксовані у Законі України «Про місцеве самоврядування в Україні». Йдеться, передусім, про «принцип гласності, підзвітності та відповідальності перед територіальними громадами органів місцевого самоврядування та їхніх посадових осіб» (ст. 4), відповідальність за дотримання вказаних положень голів рад (ст. 55, п. 14), відкритість проведення сесій та забезпечення оприлюднення їхніх рішень (ст. 46). А ст. 42 Закону закріплює обов'язок сільських, селищних, міських голів щонайменше раз на рік звітувати про свою роботу перед територіальною громадою на відкритій зустрічі з громадянами ${ }^{1}$. У той же час, зауважимо, що потреба в оновленому законі про місцеве самоврядування в Україні давно назріла, більше того, вона вже підкріплена кількома розробленими законопроєктами, які стосуються розподілу та збільшення повноважень органів місцевого самоврядування у зв'язку зі зміною адміністративно-територіального устрою. Ухвалення нового закону разом із внесенням змін до Конституції України щодо децентралізаціїумова успішного просування другого етапу реформи.

Вочевидь, зараз Україна потребує додаткових зусиль для оптимізації закладених до моделі параметрів комунікації, позаяк, судячи з даних соціологічних опитувань, суспільство не лише не відчуло покращень від упровадження реформи децентралізації, але й демонструє зниження рівня готовності до громадської участі. Так, за даними дослідження Центру Разумкова «Оцінка громадянами України наслідків реформи децентралізації і готовність брати участь у житті місцевої громади. Бачення ролі бізнесу в розвитку громад》 (травень, 2021 р.), щодо намірів громадян брати участь у громадських слуханнях, засіданнях органів місцевого самоврядування, роботі громадських рад зберігається негативна динаміка, у порівнянні з 2017 р. ${ }^{2}$. Припускаємо, що брак інформації та комунікативних взаємодій не дозволяє членам громад відчути свою причетність до розробки і втілення програм розвитку свого краю та зацікавленість влади в діалозі з суспільством. Політологиня Т. Шлемкевич обгрунтовує, що відсутність належної комунікації місцевої влади з громадою від самого початку процесу їі об'єднання та нездатність останньої до оптимізації цього процесу через брак відповідного кадрового наповнення, кваліфікаційних навчань, некоректний вибір стратегічних пріоритетів послаблюють спроможність утворених ОТГ формувати та реалізувати ключові орієнтири їхнього розвитку ${ }^{3}$

На думку професора В. Гулая, серед стратегій, спрямованих на підвищення взаємодії органів місцевого самоврядування в Україні, чільне місце повинно відіграти активне використання інструментів електронного урядування, а також формулювання й практична реалізація стратегії інформаційної відкритості органів МСВ як складової ширшої проблематики інформаційної відкритості влади загалом ${ }^{4}$. Вітчизняний дослідник $Є$. Романенко запропонував алгоритм організації контролю інформаційних потоків у системі відносин «орган державної влади - громадськість», який локалізував би комунікативні помилки на рівні зовнішньої комунікації за допомогою таких кроків:

- створення структурного підрозділу, який відповідає за стратегію і тактику комунікативної взаємодії органу державної влади і громадськості;

\footnotetext{
1 Закон Украӥни про місиеве самоврядування в Україні (зі змінами), 1997 (Верховна Рада України). Офіційний сайт Верховної Ради України <https://zakon.rada.gov.ua/laws/show/280/97-\%D0\%B2\%D1\%80\#Техt> (2021, листопад, 24)

${ }^{2}$ Центр Разумкова (2021). Оиінка громадянами Украӥни наслідків реформи децентралізації і готовність брати участь у житті місиевої громади. Бачення ролі бізнесу в розвитку громад (травень, 2021) <https://razumkov.org.ua/napriamky/sotsiologichni-doslidzhennia/otsinka-gromadianamy-ukrainy-naslidkiv-reformydetsentralizatsii-i-gotovnist-braty-uchast-u-zhytti-mistsevoi-gromady-bachennia-roli-biznesu-v-rozvytku-gromadtraven-2021r> (2021, листопад, 24).

${ }^{3}$ Шлемкевич, Т. (2020). Інформаційно-комунікаційний вимір сучасної політичної системи України: дисертачія на здобуття наукового ступеня кандидата політичних наук. Львів: ЛНУ ім. Івана Франка, 134. ${ }^{4}$ Гулай, В. (2015). Політико-комунікативні стратегії і практики взаємодії органів місцевого самоврядування України та Польщі. Украӥнська нащіональна ідея: реалії та перспективи розвитку, 27, 92-93.
} 
- забезпечення доступу керівнику такого структурного підрозділу до інформації про всі державно-управлінські рішення, які перебувають на етапі підготовки та виконання;

- кожен орган державної влади повинен мати чітко визначений перелік офіційних «ньюзмейкерів», які організовують, проводять певні комунікативні заходи із реалізації спеціальних проєктів (презентаційна діяльність), позиціонують їх у ЗМІ ${ }^{1}$.

Констатуємо, що такі практики в Україні починають здійснюватися включно й через проведення громадських слухань і публічних обговорень, звітів голів рад та ін. Зокрема, останні набувають особливого значення у форматі реакцій (дописів, коментарів, уподобань) у соціальних мережах, які з неформальних ресурсів перетворилися на напівофіційні «громадські приймальні» політиків центрального та регіонального рівнів. До прикладу, міські голови обласних центрів, що під час виборів 2020 p. здобули перемогу за підсумками першого туру, мають активні профілі у соцмережі Facebook 3 аудиторією чисельністю від 8 тис. ос. (А. Райкович, міський голова Кропивницького) до 117 тис. ос. (С. Надал, міський голова Тернополя) та 233 тис. ос. (В. Кличко, міський голова Києва $)^{23}$. I хоча присутність в Інтернеті - це вимога часу для сучасних політиків, їхня зацікавленість і в такій формі активності - це чинник конкурентоспроможності, а в межах нашого дослідження - засіб оперативної відкритої комунікації.

Висновки. Отже, у дослідженні обгрунтовано, що комунікації усистемі місцевого самоврядування - це не умовний атрибут демократизації регіонального сегменту влади у контексті децентралізаційної реформи, а невід'ємна частина функціонування органів МСВ, діяльності іiі керівників та уповноважених осіб. Запропонована дворівнева модель ефективної комунікації відповідає принципам відкритості публічної влади, запитам суспільства на прозорість ухвалення управлінських рішень, вимогам реформи децентралізації, а також нормам чинного законодавства, яким регламентовано повноваження об'єднаних територіальних громад. 3 іншого боку, чітка структурація потреб, які лягли в основу конструювання представленої моделі, дозволяє оцінити ефективність фактичної реалізації напрямків комунікації на прикладі конкретної громади, органу місцевого самоврядування, посадовця, низової організації політичної партії тощо.

\section{References:}

1. Hanzhurov, Yu. (2004). Politychna komunikatsiia: problemy strukturyzatsii [Political communication: problems of structuring]. Politychnyi menedzhment [Political management], 2, 125. [in Ukrainian].

2. Hulai, V. (2015). Polityko-komunikatyvni stratehii i praktyky vzaiemodii orhaniv mistsevoho samovriaduvannia Ukrainy ta Polshchi [Political and communicative strategies and practices of interaction between local governments of Ukraine and Poland]. Ukrainska natsionalna ideia: realii ta perspektyvy rozvytku [Ukrainian national idea: realities and prospects of development], 27, 92-93. [in Ukrainian].

3. Yedyna systema mistsevykh petytsii [Unified system of local petitions]. (2021). Holovna storinka [Homepage] <https://petition.e-dem.ua/> (2021, November, 23). [in Ukrainian].

4. Zakon Ukrainy pro mistseve samovriaduvannia v Ukraini (zi zminamy), 1997 (Verkhovna Rada Ukrainy) [Law of Ukraine on Local Self-Government in Ukraine (Verkhovna Rada of Ukraine)]. Ofitsiinyi sait Verkhovnoi Rady Ukrainy [Official website of the Verkhovna Rada of Ukraine] <https://zakon.rada.gov.ua/laws/show/280/ 97-\%D0\%B2\%D1\%80\#Text> (2021, November, 24). [in Ukrainian].

5. Komarnytskyi, V. (2020). Mistsevi orhanizatsii politychnykh partii Ukrainy v umovakh reformy detsentralizatsii [Local organizations of political parties of Ukraine in the conditions of decentralization reform]. Politykus, 1, 26. [in Ukrainian].

6. Tsentralna vyborcha komisiia [Central Election Commission] (2020). Mistsevi vybory [Local elections]. <https://www.cvk.gov.ua/pls/vm2020/wm001.html> (2021, November, 22). [in Ukrainian].

7. Nehoda, V. (2021). Rozmezhuvannia povnovazhen: na rozghliad Uriadu napravleni vazhlyvi zakonoproekty [Separation of powers: important bills have been submitted to the Government for consideration]. Detsentralizatsiia [Decentralization] <https://decentralization.gov.ua/news/13765> (2021, November, 22). [in Ukrainian].

8. Ostapenko, M. (2012). Politychna komunikatsiia: teoretychni aspekty doslidzhennia [Political communication: theoretical aspects of research]. Politychnyi menedzhment [Political management], 3, 141. [in Ukrainian].

\footnotetext{
${ }^{1}$ Романенко, С. (2014) Моделі комунікативної політики держави та інструментальне забезпечення взаємодії органів державної влади та громадськості. Науковий вісник. Демократичне врядування, 14. <http://lvivacademy.com/vidavnitstvo_1/visnyk14/fail/romanenko.pdf> (2021, листопад, 22).

${ }^{2}$ Центральна виборча комісія (2020). Місиеві вибори <https://www.cvk.gov.ua/pls/vm2020/wm001.html>

(2021, листопад, 22)

${ }^{3}$ Facebook (2021). Головна сторінка <https://uk-ua.facebook.com/> (2021, листопад, 22).
} 
9. Tsentr Razumkova [Razumkov Centre] (2021). Otsinka hromadianamy Ukrainy naslidkiv reformy detsentralizatsii $i$ hotovnist braty uchast u zhytti mistsevoi hromady. Bachennia roli biznesu v rozvytku hromad (traven, 2021) [Citizens' assessment of the consequences of decentralization reform and readiness to participate in the life of the local community. Vision of the role of business in community development (May, 2021)]. <https://razumkov.org.ua/napriamky/sotsiologichni-doslidzhennia/otsinka-gromadianamy-ukrainy-naslidkivreformy-detsentralizatsii-i-gotovnist-braty-uchast-u-zhytti-mistsevoi-gromady-bachennia-roli-biznesu-v-rozvytkugromad-traven-2021r> (2021, November, 24). [in Ukrainian].

10. Romanenko, Ye. (2014). Modeli komunikatyvnoi polityky derzhavy ta instrumentalne zabezpechennia vzaiemodii orhaniv derzhavnoi vlady ta hromadskosti [Models of communication policy of the state and instrumental support of interaction of public authorities and the public]. Naukovyi visnyk. Demokratychne vriaduvannia [Scientific Bulletin. Democratic governance], 14 〈http://lvivacademy.com/vidavnitstvo_1/visnyk14/fail/romanenko.pdf> (2021, November, 22). [in Ukrainian].

11. Semeniuk, H. (2021). Oleksiia Petrova vdruhe zvilnyly z posady holovy Zakarpatskoi oblrady [Oleksiy Petrov was fired for the second time from the post of the head of the Zakarpattia regional council]. Zaxid.net <https://zaxid.net/deputati_zakarpatskoyi_oblradi_povtorno_vidpravili_oleksiya_petrova_u_vidstavku_n1530295> (2021, November, 22). [in Ukrainian].

12. Uliutin, D. (2020). Biudzhetna detsentralizatsiia: holovni vyklyky ta dosiahnennia [Budget decentralization: main challenges and achievements]. Detsentralizatsiia [Decentralization] <https://decentralization.gov.ua/news/12661> (2021, November, 22). [in Ukrainian].

13. Chmyha, V., Rudenko, O. (2013). Komunikatyvnyi protses u mistsevomu samovriaduvanni [Communicative process in local self-government]. Kyiv: NADU. [in Ukrainian].

14. Shlemkevych, T. (2020). Informatsiino-komunikatsiinyi vymir suchasnoi politychnoi systemy Ukrainy [Information and communication dimension of the modern political system of Ukraine]: dysertatsiya na zdobuttya naukovoho stupenya kandydata politychnykh nauk [the dissertation on competition of a scientific degree of the candidate of political sciences.]. Lviv: LNU im. Ivana Franka [Ivan Franko Lviv National University].

15. Facebook (2021). Holovna storinka [Homepage] <https://uk-ua.facebook.com/> (2021, November, 22). [in Ukrainian]. 